\title{
Opinions of decision-makers on the liberalization of abortion laws in Mexico
}

\author{
Marieke G van Dijk, MD, (I) Diana Lara, MD, MPH, (1) Sandra G García, ScD. ${ }^{(2)}$
}

\section{Van Dijk MG, Lara D, García SG. \\ Opinions of decision-makers on the liberalization of abortion laws in Mexico. Salud Publica Mex 2007;49:394-400.}

\begin{abstract}
Objective. In the last decade, important advances were made in the struggle for reproductive rights in Mexico. The goal of this study was to discover the opinions of decision-makers about the grounds for legal abortion as well as to explore their perceptions about further liberalization of abortion laws countrywide. Material and Methods. In-depth interviews were conducted with eight prominent decision-makers working in governmental health, law and social institutions as well as representatives of political parties. Results. Six decision-makers favored a further liberalization of abortion laws. They proposed several strategies to move forward with liberalization. Two decision-makers were against abortion under all circumstances. Conclusions. Three factors seem to play a key role in the liberalization of abortion: a liberal party governing at the state level, a favorable public opinion and the pressure of NGOs promoting reproductive rights. A state-by-state approach seems more effective for generating changes in abortion laws.
\end{abstract}

Key words: opinions on abortion, Mexico, legal abortion, health policy

\section{Van Dijk MG, Lara D, García SG.}

Opiniones de tomadores de decisiones

sobre la liberalización de la ley del aborto en México.

Salud Publica Mex 2007;49:394-400.

\section{Resumen}

Objetivo. En la última década se realizaron avances importantes en la lucha por los derechos reproductivos en México. El objetivo del estudio fue conocer las opiniones de tomadores de decisiones (TD) sobre las causales para un aborto legal, así como explorar sus percepciones sobre la liberalización de las leyes en todo el país. Material y métodos. Se realizaron entrevistas a profundidad con ochoTD de instituciones gubernamentales de asuntos sociales, legales y de salud, así como representantes de partidos políticos. Resultados. Seis entrevistados favorecieron la liberalización de las leyes y propusieron varias estrategias para realizarla Dos entrevistados estuvieron en contra del aborto bajo cualquier circunstancia. Conclusiones. En la liberalización del aborto, tres factores parecen tener un papel relevante: un partido liberal gobernando estatalmente, una opinión pública favorable y la presión de ONG que promueven los derechos reproductivos. El trabajo estatal parece ser más efectivo para generar cambios en las leyes del aborto.

Palabras clave: opiniones sobre el aborto, México, aborto legal, políticas de salud

(I) Independent consultant.

(2) Director of the Reproductive Health Program, Population Council Mexico office.

Received on: February 26, 2007 - Accepted on: September 25, 2007 Address reprint requests to: Diana Lara. Escondida II O, col. Villa Coyoacán 04000 Coyoacán, México, DF. E-mail: dlara@popcouncil.org.mx 
O ver the last decade, important successes took place in the struggle for the recognition of sexual and reproductive rights in Mexico. A major breakthrough was the decriminalization of abortion during the first 12 weeks of gestation in the Federal District (Mexico City) by the Legislative Assembly in April 2007; this is especially significant given that the present ruling party at the federal level is the conservative Partido Acción Nacional (PAN) -a party with strong ties to the Roman Catholic Church-. The bill was approved by 46 of the 66 representatives and includes not only the decriminalization of abortion up to 12 weeks, but also reduced sentences for women undergoing abortion after 12 weeks and the definition of pregnancy beginning at implantation. ${ }^{1}$

At the International Conference on Population and Development in 1994, Mexico along with other countries affirmed its commitment to take steps to ensure that unsafe abortion would be addressed as an important public health problem. ${ }^{2}$ Mexico has a federal system in which each state has its own laws; abortion in the case of rape is the only circumstance permitted in all 32 states. The other circumstances under which abortion can be performed legally vary from state to state (table I). ${ }^{3}$ The Federal District is the only state where abortion is legal for any reason for up to 12 weeks. This achievement was preceded by a series of important events. The case of Paulina del Carmen Ramirez Jacinto in 1999, for example, was a precursor to public awareness and received significant media attention. Paulina was a 13-year-old girl from Mexicali, Baja California, who became pregnant after being raped. Although she received permission to obtain a legal abortion, the hospital convinced

\section{Table I}

\section{GROUNDS FOR LEGAL ABORTION IN THE 32 Mexican STATEs ${ }^{3}$}

Ground for legal abortion

Number of states

\begin{tabular}{ll} 
When the pregnancy is the result of rape & 32 \\
\hline When the life of the woman is in danger & 29 \\
\hline When the health of the woman is in danger & 10 \\
\hline When the fetus has severe mental or physical deformities & 13 \\
\hline When the abortion results from a "negligent or careless" \\
act by the pregnant woman
\end{tabular}

Economic hardship, when a woman already has three

children and can prove that she lacks the economic

resources to support another child

I (Yucatan) her mother through misleading information to decline the abortion. The Mexican society was shaken by the details of Paulina's case. ${ }^{4,5}$

The following year, in 2000, PRD (Partido de la Revolución Democrática) Federal District Interim Mayor Rosario Robles introduced a bill in the Federal District Legislative Assembly to make fetal impairments and risk to the woman's health exemptions in the penal code ("Robles Law"), which was passed despite objections by the PAN. ${ }^{4,6}$ A significant advance in this legislative reform was the definition of responsibilities for the judicial and health sectors, and the process for providing legal abortion services following rape. In 2002, the Federal District Ministry of Health (MOH) issued guidelines on the organization and operation of legal abortion services in public hospitals, to improve the actual access to abortion. ${ }^{7,8}$

Other states have also modified their laws over the years, such as Morelos, where the abortion law was liberalized on several grounds in the year 2000. ${ }^{4}$ It is difficult to know whether in the years to come other Mexican states will follow the Federal District example. Although the conservative federal government may oppose such legal reforms, the relative autonomy of the decentralized states may facilitate the liberalization process. The qualitative study herein was conducted in order to explore the perspectives on the liberalization of abortion in Mexico of prominent decision-makers in the field of reproductive health. At the time of the study, it was not known that abortion in the Federal District would be decriminalized or that PAN candidate Felipe Calderón would win the presidential elections. However, the opinions of the decision-makers provide a clear reflection of the discussion on the pros and cons of the decriminalization of abortion in Mexico.

\section{Material and Methods}

After consulting with leading women's groups in the Federal District, co-investigators identified a list of 13 key decision-makers at the national level, including politicians, cabinet members, Ministry of Health $(\mathrm{MOH})$ officials, and high-profile clinicians and researchers. Due to difficulties in obtaining appointments with busy public officials, an experienced qualitative interviewer ultimately carried out eight interviews between August 2005 and March 2006. Using a semi-structured interview guide, the decision-makers were asked about their opinions on the circumstances for legal abortion, the situation in the different states, the participation of the church in the abortion discussion and their opinions on how to proceed with abortion legislation in the future. Two re- 
searchers independently read each interview transcript, identified emergent themes within the text, and coded the data; one used the qualitative data analysis program Atlas-ti for coding, and the other researcher conducted a traditional manual analysis. All participants gave oral consent and they were assured of their anonymity. The research proposal was approved by the Internal Review Board of the Population Council.

\section{Results}

Seven decision-makers had high-level positions in governmental institutions concerned with health, gender equity and law at the moment of the interview. One respondent belonged to an association of health professionals (table II).

\section{Opinions on the grounds for legal abortion}

The decision-makers were asked their opinions on reasons for which a legal abortion should be permitted. The legalization circumstances in the Federal District in 2000 were discussed: rape, serious danger to the woman's health and congenital malformations of the fetus.

Most decision-makers (six of eight) fully agreed that pregnancy as a result of rape should be an indication for legal abortion. Two of the six affirmed that in these cases abortion is a fundamental right of women to decide over their own bodies and that no woman should be obliged to carry a child she does not want because it is the result of rape: "We should not be that close-minded. We do not live in the cave era in which human rights were not respected". One of them argued that these women should be able to count on well-established procedures for having an abortion without being stigmatized. Two conservative decisionmakers acknowledged that while pregnancy following rape was very difficult for a woman, they expressed clear opposition to legal abortion under such circumstance. One noted the possibility that the offender could regret his act and assume his responsibilities as a father, and also pointed out that when uncertainty exists about the offender, DNA tests can be done on suspects to identify the father.

The majority of the decision-makers (seven of eight), however, agreed that abortion should be legal when the health of the woman is in grave danger. Still, one argued that in these cases one should consider the "other" life: "These situations or these justifications also have ethical counterarguments that in many cases don't accept that a life is destroyed, even when it is being attempted to preserve another, which would be the extreme case".

When serious congenital or genetic defects have been detected in the fetus, all of the decision-makers but one agreed with legal abortion for this indication. A

Table II

Characteristics of the Respondents

\begin{tabular}{|c|c|c|c|}
\hline \# & Sex & Institution/organization: & Education/experience (a.o.) \\
\hline I & $\mathrm{F}$ & Ministry of Health & $\begin{array}{l}\text { Medical doctor, politics, HIVIAIDS, reproductive } \\
\text { health }\end{array}$ \\
\hline 2 & $\mathrm{~F}$ & Ministry of Health of the Federal District & Medical doctor, public health, social sciences, politics \\
\hline 3 & $\mathrm{~F}$ & $\begin{array}{l}\text { Chamber of Deputies, member of PRI (Partido Revolucionario Institucional), } \\
\text { Committee on Equity and Gender (Comisión de Equidad y Género) }\end{array}$ & Lawyer, social and family law, politics \\
\hline 4 & M & $\begin{array}{l}\text { Chamber of Deputies, member of PAN (Partido Acción Nacional) Health } \\
\text { Committee PAN }\end{array}$ & $\begin{array}{l}\text { Medical doctor, management of medical schools, } \\
\text { politics }\end{array}$ \\
\hline 5 & M & $\begin{array}{l}\text { Senate of the Republic, member of PAN Senatorial Committee on Equity } \\
\text { and Gender (Comisión de Equidad y Género del Senado) }\end{array}$ & Politics \\
\hline 6 & $\mathrm{~F}$ & $\begin{array}{l}\text { Ministry of Social } \\
\text { Development (Instituto Nacional de Desarrollo Social, INDESOL) }\end{array}$ & Anthropology, politics, social development \\
\hline 7 & M & $\begin{array}{l}\text { Mexican Federation of Gynecology and Obstetrics (Federación Mexicana de } \\
\text { Ginecología y Obstetricia, FEMEGO) }\end{array}$ & $\begin{array}{l}\text { Medical doctor, reproductive health experience in } \\
\text { NGOs and important G\&O institutions }\end{array}$ \\
\hline 8 & $\mathrm{~F}$ & $\begin{array}{l}\text { Attorney General Office of the Republic (Procuraduria General de la } \\
\text { República, PGR) }\end{array}$ & Victim assistance, law \\
\hline
\end{tabular}


key supporting argument was that not all families can meet the special needs of these children and offer them a life with dignity and quality.

\section{Opinions on further liberalization of abortion laws}

The majority of the decision-makers (six of eight) felt that the process of decriminalization of abortion laws in Mexico (on a state-by-state basis) -including an explicit extension of the circumstances for legal abortion-should be continued and they cited four main reasons to support their views: First, that women have a fundamental right to decide over their bodies and that this right prevails over the embryo's right to live. Of course, they said, the embryo has a value, but: "How can you worry about the unborn, instead of worrying about the woman in whom it actually lives?" Second, that along with contraception, abortion was considered invaluable to preventing unwanted pregnancies: "For a woman who really has an unwanted pregnancy, in her perception she is not pregnant. In biological terms it is the same, it is an embryo and everything; but no, for her it is not that, it is not a child, it is not a baby, it is not a pregnancy, it is as if it were a cancer". Third, that abortion helps prevent unwanted children from growing up in sad conditions. Many respondents felt strongly that unwanted children have a greater likelihood of being raised unloved and maltreated, and perhaps turning to a life of criminality; and finally, that legalizing abortion would ultimately prevent the mortality and morbidity associated with unsafe clandestine abortion. Furthermore, medical institutions would be obliged to offer good-quality services to the women, and women would be protected by the law, even in cases of conscientious objection.

Two decision-makers were against any further legalization of abortion laws and had serious doubts about the legal practice of existing circumstances. The three main reasons they cited were: that the fetus's life should be protected over a woman's life:

\footnotetext{
"There is a life inside, that has no possibility of defending itself, [...] so the State has to defend that life, the society has to defend that life, [...] it would be a human being that they are killing"; that Mexicans "are not prepared" for permissive abortion laws and women would "abuse" these laws and disregard any responsibility over their sexual lives; and that abortion poses serious psychological consequences to women that should be clarified and understood.
}

\section{Factors affecting further liberalization of abortion laws}

The six decision-makers favoring liberalization of abortion laws nevertheless observed that advances in the coming years will depend on a series of factors:

\footnotetext{
Several respondents saw the liberalization of abortion laws in Mexico as a gradual social process and felt that the abortion issue is still very stigmatized for most Mexicans. These respondents felt that a good "thermometer", however, would be the public's response to the changes in the abortion laws in the Federal District. One of the decision-makers felt optimistic because she had observed that "an important cultural change has taken place in Mexico over the last 15 years". She noted that Mexican women are starting to claim their rights, and her impression was that a further advance in the society's acceptance of abortion will indeed take place: "I think, as for including more circumstances, it has to be like a maturation of the society and I think this way it also [...] gives less space for a polarization of the different opinions".
}

Respondents also mentioned the 2006 presidential elections as a key determinant of whether or not further liberalization of abortion laws would be possible (recall that these interviews took place before the July 2006 elections in which Felipe Calderón of the PAN party won). Most respondents felt that advances in the discussion of the liberalization of abortion laws would be difficult under PAN governance and while nearly all respondents acknowledged Mexico's historical tradition of separation of church and state, some respondents commented that the Catholic Church has a (too) strong influence on the PAN party: "The Church, not with one hand, with its whole body, is inserted in one of the parties of this country which is so strong that it is governing $[. .$.$] so$ this is very serious; it is battling with a very powerful force, you know that the Vatican has a tremendous power and its opinion in spiritual areas is seen from another perspective, that is, they are sent by the Lord, their word is law, so all this has influenced and has inhibited us to walk as we should. The separation is a fallacy, at least on the issue of reproductive and sexual health, especially on the issue of abortion; the separation between church and state is a fallacy".

While many of the respondents supported extending legal abortion across the various states, they were also quick to point out that whether or not this is possible will depend on state politics and governors. For 
example, while every state in Mexico allows for abortion in the case of rape, only three states have signed agreements on the steps to take for a legal abortion in the case of rape. Further, agreements made at the national or international level are often not applied in the states: "There are laws that give a positive juridical framework [for abortion] and it results that, at the state level, it is impressive, there is a great heterogeneity and there is not even a harmonization with the federal questions or with these international agreements signed by the country".

Many respondents felt that NGOs and women's groups should be more vocal, more persistent and much more critical in assessing governmental activities and expenditures. They agreed that women's groups should pressure the government to account for their expenses in the area of women's reproductive and sexual health, but also noted that strategy was key. While most respondents were sympathetic to sharp declines in recent available funding for those groups working on sexual and reproductive health and rights, they nevertheless shared the view that some women's groups do not always exercise good judgment when picking and choosing their battles. One example cited was that during the Mexican $\mathrm{MOH}$ 's discussions to include emergency contraception (EC) in the family planning norms (2003), some NGOs chose to attack the $\mathrm{MOH}$ for its lack of action on the topic of abortion rather than supporting the EC efforts.

\section{Strategies for proceeding with the liberalization of abortion laws}

The six decision-makers who favor further liberalization of abortion laws proposed a range of possible solutions or pathways to move ahead with a pro-choice agenda.

A few respondents felt that the word "abortion" is stigmatized to such an extent in Mexican society that abortion will never be fully legalized as it is in some countries. They also argued that the controversies provoked by the term itself have made constructive dialogue challenging and that, perhaps, a symbolic change in discourse was needed to focus attention on the right of the state to provide high-quality health service to women.

Furthermore, most supporters of continued liberalization felt that the $\mathrm{MOH}$ should continue being comprised of and working with individuals who construct policies and normative guidelines based on scientific evidence and best practices, and not based on "their personal perception and dogmas". Many felt that it was appropriate for NGOs and civil women's organizations to support the $\mathrm{MOH}$ when it tackles controversial re- productive health issues such as abortion. According to them, the $\mathrm{MOH}$ should also put more effort on providing a stronger counterbalance to conservative groups, particularly since conservative groups use impressive strategies with which to oppose to the legalization of abortion.

These six respondents also highlighted the importance of a continuous effort to sensitize and raise awareness of state governments and local public officials on the public health and reproductive rights arguments in support of legal abortion, particularly if one goal of liberalization of abortion laws were to replicate the model in effect in the Federal District. A state-by-state approach, they argued, while slow and cumbersome, would perhaps be more effective than trying to make sweeping reforms at the federal level. For this reason, many felt that the key civil women's groups that are now concentrated in the bigger cities should decentralize and ensure a presence in the states. These respondents also felt strongly that training and sensitization workshops with health providers on the implications of implementing the new abortion laws would in time bring about a higher acceptance of legal abortion.

Three of the six decision-makers agreed that ongoing research should be done to document the attitude of the general public as well as health providers and other important stakeholders regarding further liberalization of abortion laws. As one respondent noted: "I think it is also important to have opinion polls in order to know at what moment to take what measure, that is, a bit like if one thinks there should be a decriminalization or legalization of abortion in a large number of circumstances. I think it is important not to open at the wrong time... let's say it is like how one builds a strategy".

The six respondents acknowledged that there were many actors in Mexico's abortion debate and that work on further liberalization of laws would require knowing and understanding each of the players well. For example, one respondent talked about the constant struggle for power between the medical community, the church, social scientists and the general public, especially women. He proposed that each stakeholder should try to understand and respect each other's work and opinions and avoid extreme opinions because "we live in a plural society". Similarly, he argued that a starting point for dialogue should be a common objective, which in his opinion should be improving the quality of care for women. These six respondents agreed that debate and dialogue should be in the form of well-organized multidisciplinary meetings with clear objectives and rules. National and international specialists should be consulted and invited to give their views on these topics. 


\section{Discussion}

The decision-makers in this study, whether supportive (six out of eight) or not of further liberalization of abortion laws in Mexico, expressed their opinions freely and without apparent reservation. Even with this small sample, particularly among the six respondents who held more liberal views on abortion legislation, we are confident that saturation was achieved as most of the key issues were echoed among the six. However, since only two respondents held views clearly opposed to abortion generally and to further liberalization of laws, we cannot be sure that saturation was achieved with this small group of anti-choice decision-makers.

Most of the respondents expressed support for the possibility of legal abortion in the circumstances of rape, to safeguard a woman's health and in cases of severe congenital malformations. At the same time, the majority of the respondents were of the opinion that abortion should further be legalized for several reasons: the protection of the woman's rights, the prevention of unwanted pregnancies, the social consequences of unwanted children and the prevention of unsafe clandestine abortions. Two respondents disagreed with a further legalization of abortion. They argued the state should defend the fetus's life and they expressed concerns about the psychological consequences of an abortion and the society's possible abuse of the method.

It is worth noting that respondents overestimated the role of the conservative party of the presidency as a negative factor for the further liberalization of abortion laws. Although anti-choice activists held public protests and the Catholic Church announced that people involved in promoting abortion would be excommunicated, they were not able to block the modification of the law. Even while having a conservative federal government, the governing political parties in the states can promote changes in favor of women's sexual and reproductive health, as was achieved by the PRD in the Federal District.

Another important factor that influenced the introduction of permissive abortion laws in the Federal District was the favorable public discussion regarding abortion. Two opinion polls conducted in the Federal District (before and after the modification in April 2007) revealed that $38 \%$ of the respondents agreed with offering legal abortion in the first 12 weeks of pregnancy if it "affects the woman's life project". * Sixty percent

\footnotetext{
* Population Council. Encuesta de opinión sobre las reformas del D.F. para aborto legal 15-17 Abril 2007: resultados preliminares (Unpublished report).
}

answered that they would agree if the approved law would be extended to the rest of the country and the same percentage considered that the state $\mathrm{MOH}$ was acting in a responsible way towards women's health. * In contrast, a national opinion poll conducted in 2006 reported that only $12 \%$ of respondents think abortion must be permitted in all circumstances and $26 \%$ stated that abortion should be illegal in all circumstances. ${ }^{9,7}$ These figures indicate that in the Federal District, secularization and religious diversity have slowly increased and people's moral values have changed compared to the Mexican society as a whole.

Furthermore, NGOs that promote sexual and reproductive health and rights have a strong presence in the Federal District. These groups sensitize the public and pressure the government through activities such as advocacy, research, training and health education. However, as noted by some respondents, the main NGOs are still concentrated in the capital city.

One of the lessons learned by the study herein is that states governed by liberal parties, with a more open public opinion and strong NGO representation, have more opportunities to generate liberal laws than states with conservative leadership, less liberal societies and little presence of NGOs promoting sexual and reproductive rights. As mentioned by one of the respondents, a patient and stepwise state-by-state approach could lead to more effective reforms in abortion laws than an attempt to modify the law at the federal level.

\section{Acknowledgements}

We wish to thank our participants, our interviewer and consultants who helped transcribe the data. This project was supported by an anonymous donor.

\section{References}

I. GIRE. Today marks a historic day in Mexico and the Latin American region. April 24, 2007. Avalailable at: www.gire.org.mx/contenido. php? informacion= 187 [Consulted 4 June 2007] 2. UNFPA. Summary of the ICPD Programme of Action. Available at: http:// www.unfpa.org/icpd/summary.htm [Consulted 5 June 2007] 3. GIRE. Cifras del aborto en México. Available at: http://www.gire.org. $\mathrm{mx} /$ contenido.php? informacion=3 [Consulted II June 2007)

* Population Council. Encuesta de opinión sobre las reformas de D.F. para aborto legal, 28 mayo 2007: resultados preliminares (Unpublished report).

₹ Population Council. Encuesta de opinión pública sobre el aborto 2006: resultados preliminares (Unpublished report). 
4. Lamas M, Bissell S.Abortion and politics in Mexico: context is all. Rep Health Matters 2000:8:10-23

5. Taracena R. Social actors and discourse on abortion in the Mexican press: the Paulina case. Rep Health Matters 2002;10:103-I I0.

6. Asamblea Legislativa del Distrito Federal. Decreto por el que se reforman y adicionan diversas disposiciones del código penal para el Distrito Federal y del código de procedimientos penales para el Distrito Federal. Mexico City: Gaceta Oficial del Distrito Federal, 2000; 148:2-3. 7. Billings DL, Moreno C, Ramos C, González de León D, Ramírez R, Villaseñor $L$ et al. Constructing access to legal abortion services in Mexico City. Rep Health Matters 2002;10:86-94.
8. Lara D, García SG, Strickler J, Martínez H,Villanueva L. El acceso al aborto legal de las mujeres embarazadas por violación en la Ciudad de México. Gac Med Mex 2003;139:S77-S90.

9. García SG, Tatum C, Becker D, Swanson K, Lockwood K, Ellertson C. Policy implications of a national public opinion survey on abortion in Mexico. Rep Health Matters 2003; 12:65-74. 